\title{
Mountain Biodiversity patterns in Southern Europe and North Africa
}

\author{
Rosario G. Gavilán (*), Borja Jiménez-Alfaro (**), Gianluigi Bacchetta (***), \\ Panayotis Dimopoulos (****) \& Ladislav Mucina (*****)
}

\begin{abstract}
Gavilán, R.G., Jiménez-Alfaro, B., Bacchetta, G., Dimopoulos, P. \& Mucina, L. Mountain Biodiversity patterns in Southern Europe and North Africa. Lazaroa 34: 07-10 (2013).

About $19 \%$ of European population lives in mountainous regions - a notably more than the global average. The 50\% of the Earth's population depends on the mountain resources, mainly on drinking and industrial water and energy. However, the role of the mountain regions as place of recreation and leisure should not be underestimated as it is a major source economic force in some countries but also one of sources of problems creating pressure on mountain biota and landscapes.

Lazaroa, Journal of Botany, presents this Feature with a collection of papers focused on Biodiversity of South Europe and Northern Africa mountain ranges. Geographically, it covers the main mountain chains of Europe and of North Africa, including those of the Balkans, Dinarides, Apennines, Pyrennees, Cantabrian Mts, Sierra Nevada and a whole array of other Mediterranean mountain ranges such as the Sistema Central in the Iberian Peninsula and those of Portugal and Sicily, and finally the Atlas of North Africa.
\end{abstract}

Keywords: Mediterranean Region, Alpine biodiversity, Biogeography, plant species, vegetation.

Resumen: Gavilán, R.G., Jiménez-Alfaro, B., Bacchetta, G., Dimopoulos, P. \& Mucina, L. Modelos de diversidad de las montañas del sur de Europa y norte de África. Lazaroa 34: 7-10 (2013).

El 19\% aproximadamente de la población europea viven en zonas de montaña, algo más que la media de todo el planeta. El 50\% de la población terrestre depende de los recursos de las montañas que, principalmente, proceden del agua como fuente de energía y abastecimiento. Sin embargo, en numerosos países son también fuente recreativa y de tiempo libre y este uso no debe ser subestimado pues supone una fuerza económica muy importante que crea problemas de conservación de la biodiversidad, así como en los paisajes naturales.

Lazaroa, Revista de Botánica, a través del presente volumen especial presenta un conjunto de trabajos sobre la biodiversidad de las montañas del sur de Europa y norte de África. Geográficamente cubre las principales cadenas de estos territorios como los Balcanes, Dináridas, Apeninos, Pirineos, Cordillera Cantábrica, Sierra Nevada y otro grupo de montañas Mediterráneas como el Sistema Central en la Península Ibérica, junto a otras de Portugal y Sicilia y, finalmente, el Atlas en el norte de África.

Palabras clave: Región Mediterránea, biodiversidad alpina, Biogeografía, especies vegetales, vegetación.

\section{EDITORIAL}

Mountains cover only a small fraction of the Earth's surface yet they support approximately one-third of biodiversity (SPEHN \& al., 2011) facing various types of pressures associated with the impact of global change, resulting in serious conservation challenges (STEFFEN \& al., 2003;

* Departamento de Biología Vegetal II. Facultad de Farmacia. Universidad Complutense. E 28040. Madrid, Spain. Email: rgavilan@ucm.es.

** Department of Botany and Zoology. Masaryk University. Kotlarska 2, CZ-61137. Czechia. Email: borja@sci.muni.cz

*** Centro Conservazione Biodiversità (CCB). Dipartimento di Scienze della Vita e dell'Ambiente. Università degli Studi di Cagliari. v.le Sant'Ignazio da Laconi, 13. I 09123.Cagliari, Italia. Email: bacchet@unica.it

**** Department of Environmental and Natural Resources Management. University of Patras. 2 Georgiou Seferi St. Agrinio, Greece. Email: pdimopul@uwg.gr

***** School of Plant Biology M084. The University of Western Australia. 35 Stirling Highway. Crawley WA 6009, Australia. Email: laco.mucina@uwa.edu.au 


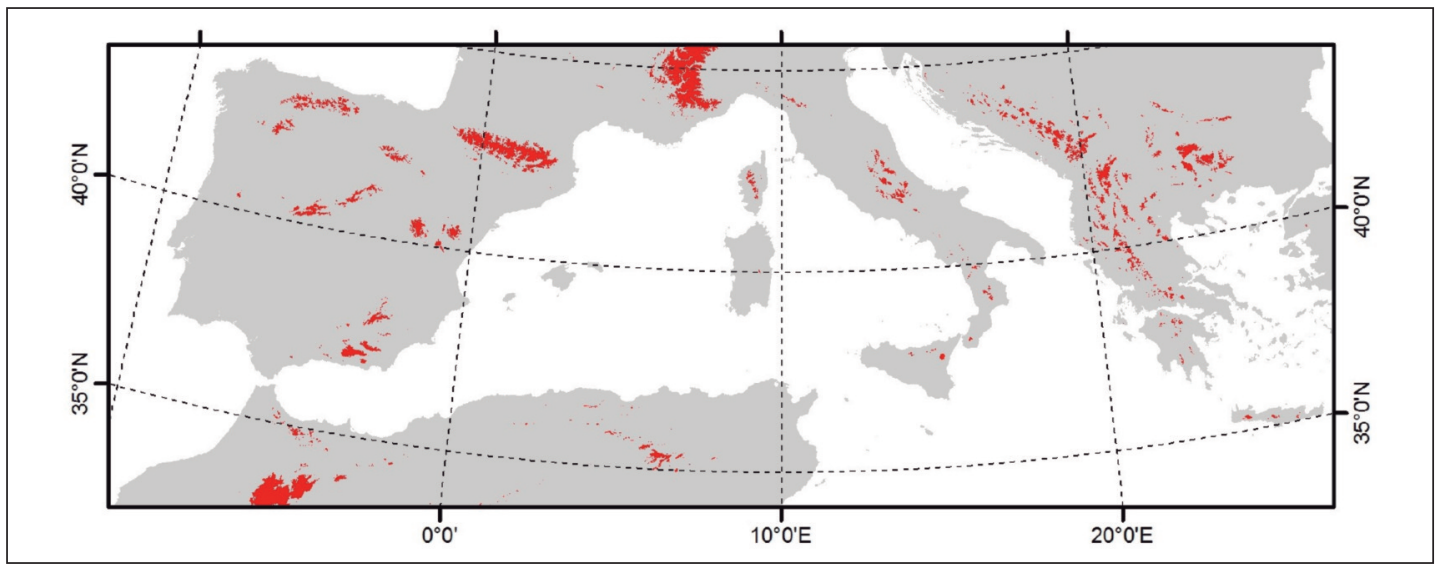

Figure 1. - Southern Europe and Northern Africa Mountains. Most of them cover the papers of this Special Feature.

FieLD \& al., 2013). In Europe, the $25 \%$ of the flora is found in the mountains and many of the mountain plants, especially in Southern Europe, are endemics. About 19\% of European population lives in the mountainous regions - a notably more than would be the global average of $12 \%$ (PAULI \& al., 2004). However, $50 \%$ of the Earth's population depends on the mountain resources, mainly on drinking and industrial water and energy. The role of the mountain regions as place of recreation and leisure should not be underestimated as it is a major source economic force in some countries but also one of sources of problems creating pressure on mountain biota and landscapes.

This special Feature of Lazaroa presents a collection of papers focused on biodiversity of South European mountain ranges. Geographically, this region covers the main mountain chains of Europe and of North Africa, including those of the Balkans, Dinarides, Apennines, Pyrennees, Cantabrian Mts, Sierra Nevada and a whole array of other Mediterranean mountain ranges such as the Sistema Central in the Iberian Peninsula and those of Portugal and Sicily, and finally the Atlas of North Africa (Figure 1).

Alpine and oromediterranean belts are ecologically and evolutionary extremely important regions. They serve as water reservoirs and are home to rare and endemic biodiversity. Water supply in Southern Europe and in circummediterranean countries has always been a serious issue for the governments of the concerned countries. We suggest that the targeted conservation of na- tural vegetation of these regions will guarantee slope stabilization and prevent erosion processes that may impact on plant communities at lower altitudes and exert strong negative effect on the capacity of water reservoirs downhill (GAVILÁN \& GuTIÉRREZ, 2009).

Monitoring alpine biodiversity in a broad global framework is the aim of a very successful international initiative called GLORIA (PAULI \& al., 2004). The data collected by a GLORIA team within a relative short-term (2001-2008) have documented changes in vascular plant species richness as well as cover and composition of vegetation on four summits in the Sierra Nevada (Spain) presenting upon evidence about possible climate change impact on the alpine plant communities (FERNÁNDEZ CAlZAdo \& Molero, 2013). Short-term studies in combination with long-term GLORIA data could increase our understanding of these habitats and allow predictions of future responses of the biota to global change (GUTIÉRREZ GIRÓN \& GAVILÁN, 2013). Moreover, FRATTAROLI \& al. (2013) study seed germination capability of alpine endemics (Adonis distorta, Androsace mathildae) together to other mountain endemic species (Aquilegia magellensis and Campanula fragilis subsp. cavolinii) from the Central Apennines (Italy). These germination protocols are essential to population reinforcement projects of endangered species in the Central Apennines.

Mountain biodiversity is also an important subject to analyze biogeographical patterns related to evolutionary history and ecology of plant species. 
Because of historical processes, many arctic-alpine species in Europe find their southern distribution limit in Bulgarian mountains (the Balkans and other) and are listed as threatened in the country. APOSTOLOVA \& al. (2013) show how these species follow similar patterns of survival and tend to live together, as a possible unified strategy to live in harsh environments. In the Pyrenees, NINOT \& al. (2013) demonstrate patterns of functional, ecological and phytogeographic plant groups with consistent shifts along an altitudinal gradient. They found landscape singularities and accounted for differences between axial Pyrenean and pre-Pyrenean sectors, differences which are related to migration, extinction, and diversification over major Quaternary climatic variation. Reconstruction of past flora throughout palaeobotanical analysis is in fact an interesting tool for evaluating environmental constraints for species. PÉREZ \& al. (2013) use this approach to analyze the Holocene evolution of the yew (Taxus baccata) in the Basque Mountains (Iberian Peninsula) showing periods of expansion during the Middle Holocene and a regression phase in the Late Holocene. In addition, LóPEZ SÁEZ \& al. (2013) offer new insights in the history of Mediterranean mountain vegetation from the study of pollen in Scots pine (Pinus sylvestris) forests. They found a strong relationship between altitude, temperature, rainfall, canopy cover and variations in pollen taxa percentages to propose new plant communities to be considered in the Iberian Peninsula.

Taxonomical diversity is still a relevant issue of mountain biodiversity with a high impact on the development of conservation strategies of species and plant communities. Following a long-term project on the difficult genus Pilosella (Asteraceae), EgIDO \& MATEO (2013) describe three new species in the alpine range of the Cantabrian Range. These species have a hybrid origin from $P$. argyrocoma, endemic to the Iberian Peninsula and Northern Africa, reflecting the importance of geographic isolation in the evolution of mountain flora. AMICH \& BERNARDOS (2013) show a detailed description of the distribution and ecology of Fritillaria caballeroi, an endemic threatened plant whose distribution is restricted to the mountains of the western sector of the Central System (Tormantos, Béjar, Francia and Estrela) and the Mon- tes de León, up to $1500 \mathrm{~m}$ asl. In Northern Africa, territories from the Middle Atlas (Marmoucha, Morocco) are also considered very rich in endemic, rare, and endangered species. This high diversity has been analyzed by NASSIF \& TANJI (2013) in an ethnobotanical exploration among the Berbers, assessing the extent of plant diversity in poorly-surveyed areas. In the other extreme of the Mediterranean basin, PUGLISI \& al. (2013) report new records for the bryological flora of Macedonia and Albania, such as Scapania cuspiduligera and Distichium inclinatum, and bryo-cormophytic communities of Ctenidietea mollusci and Montio fontanae-Cardaminetea amarae. Finally, the pharmacological activity of a Mediterranean species (Salvia lavandulifolia) common in mountain and foothill calcareous shrublands is also extensively revised (PORRES-MARTíNEZ \& al., 2013).

Mediterranean mountains are also refuges for vegetation types that find in these regions unique ecological conditions. Indicator species analyses (DuFrêNE \& LEGENDRE, 1997; De CÁCERES \& al., 2010) applied to phytosociological data is able to reveal the main characteristics of these vegetation types. VILCHES \& al. (2013) apply this method to study the case of Quercus pyrenaica forests in eastern areas of the Iberian Peninsula, describing new mountain forests close to the coast and their main serial communities. In other cases, the exploration of the diagnostic species in combination with the topographic patterns of the community diversity brought out the interpretation of transitional communities. This is explored by RodRíGUEZ-RoJo\& al. (2013) in xeric continental communities of Festucetum hystricis and semi-dry variant of Plantago maritima subsp. serpentina in the central-eastern mountains of the Iberian Peninsula. AgUIAR \& al. (2013), on the other hand, study ultramafic vegetation in the northeastern mountains of Portugal and describe new communities included in one vegetation series (Genisto hystricis-Querco rotundifoliae $S$.). A similar approach is used by SCIANDRELLO \& al. (2013) to analyze anthropogenic influences on plant communities at the landscape level. They reconstruct the vegetation of the Taormina region (Messina, Sicily) using vegetation series and landscape units to observe vestiges of natural vegetation and to make proposals for their preservation. 


\section{REFERENCES}

Aguiar, C., Monteiro-Henriques, T. \& Sánchez-Mata, D. 2013 - New contributions on Flora and Vegetation of northeastern Portugal ultramafic outcrops - Lazaroa 34: 141-150.

Amich, F. \& Bernardos, S. - 2013- Chorology and habitat characterization of Fritillaria caballeroi a endemic and threatened species in the Central System (Iberian Peninsula) - Lazaroa 34: 19-27.

Apostlova, I., Pedashenko, H., Sopotlieva, D., Velev, N., Vassilev K. \& Meshine, T. -2013-Arctic-alpine plants in Bulgarian mountains - Lazaroa 34: 55-63.

De Cáceres, M., Legendre, P. \& Moretti, M. -2010 - Improving indicator species analysis by combining groups of sites - Oikos 119: 1674-1684.

del Egido Mazuelas, F. \& Mateo Sanz, G. -2013 - Pilosella argyrogaliciana, P. argyrolegionensis and P. megargyrocoma (Asteraceae): three new species from the Cantabrian Mountains (N Spain) - Lazaroa 34: 11-17.

Dufrêne, M. \& Legendre, P. - 1997- Species assemblages and indicator species: the need for a flexible asymmetrical approach - Ecol. Monogr. 67(3): 345-366.

Fernández Calzado, M.R. \& Molero Mesa, J. -2013Changes in the summit flora of a Mediterranean mountain (Sierra Nevada, Spain) as a possible effect of climate change - Lazaroa 34: 65-75.

Frattaroli, A.R., Di Martino, L., Di Cecco, V., Catoni, R., Varone, L., Di Santo, M. \& Gratani, L. -2013- Seed germination capability of four endemic species in the Central Apennines in Italy: relationships with seed size - Lazaroa 34: 43-53.

Field, C.B., Barros, V., Stocker, T.F., Qin, D., Dokken, D.J., Ebi, K.L., Mastrandrea, M.D., Mach, K.J., Plattner, G.K., Allen, S.K., Tignor, M. \& Midgley, P.M. (Eds.) 2012 - Managing the risks of extreme events and disasters to advance climate change adaptation - Cambridge Univ. Press, Cambridge and New York.

Gavilán, R.G. \& Gutiérrez Girón, A. -2009- The importance of Mediterranean alpine biodiversity in Central Spain - Mount. Forum Bull. 9(2): 54-55.

Gutiérrez Girón, A. \& Gavilán, R.G. -2013- Monitoring Mediterranean high mountain vegetation in Sistema Central: GLORIA project and collateral ecological studies - Lazaroa 34: 77-87.

López-Sáez, J.A., Sánchez-Mata, D., Alba-Sánchez, F., Abel-Schaad, D., Gavilán, R.G. \& Pérez-Díaz, S. 2013 - Discrimination of Scots pine forests in the Ibe- rian Central System (Pinus sylvestris var. iberica, Pinaceae) by means of pollen analysis. Phytosociological considerations - Lazaroa 34: 191-208.

Nassif, F. \& Tanji, A. - 2013 - Floristic analysis of Marmoucha's plant diversity (Middle Atlas, Morocco). Lazaroa 34: 117-140.

Ninot, J.M., Ferré, A., Grau, O., Font, X., Pérez-Haase, A. \& Carrillo, E. - 2013- Environmental drivers and plant species diversity in the Catalan and Andorran Pyrenees - Lazaroa 34: 89-105.

Pauli, H., Gotffried, M., Hohenwallner, D., Reiter, K., Casale, R., Grabherr, G. - 2004- The GLORIA field manual - Multi-Summit approach. European Commission, Luxembourg.

Pérez-Díaz, S., López-Sáez, J.A., Ruiz-Alonso, M., Zapata, L., \& Abel-Schaad, D. -2013- Holocene history of Taxus baccata in the Basque Mountains (Northern Iberian Peninsula) - Lazaroa 34: 29-41.

Porres-Martinez, M., Carretero, M.E. \& Gomez-Serranillos, M.P. - 2013 - Pharmacological activity of Salvia lavandulifolia and chemical components of its essential oil - Lazaroa 34: 237-254.

Puglisi, M., Campisi, P., Lakušić, D., Surina, B., Di Pietro, R., Privitera, M. - 2013 - Notes on the bryophyte flora and vegetation of the central and south-western Balkans - Lazaroa 34: 107-116.

Rodríguez-Rojo, M.P., Sardinero, S. \& Fernández-González, F. - 2013- Patterns of community and species diversity in grassland vegetation of the southwestern Iberian System - Lazaroa 34: 219-236.

Sciandrello, S., D’Agostino, S. \& Minissale, P. -2013Vegetation analysis of the Taormina Region in Sicily: a plant landscape characterized by geomorphology variability and both ancient and recent anthropogenic influences - Lazaroa 34: 151-190.

Spehn, E., Rudmann-Maurer, K. \& Körner, Ch. -2011Mountain biodiversity -Plant Ecol. Div. 4(4): 301-302.

Steffen, W., Sanderson, A., Tyson, P.D., Jäger, J., Matson, P.A., More III, B., Oldfield, F., Richardson, K., Schellnhuber, H.J., Turner II, B.L. \& Wasson, R.J. -2003Global change and the Earth system. A planet under pressure - Springer, Berlin

Vilches de la Serna, B., Merle, H., Ferriol, M., SánchezMata, D. \& Gavilán, R.G. -2013- A new Iberian broadleaved oak forest in the eastern coastal mountains and seral plant communities - Lazaroa 34: 209-217. 